\section{Research Article}

(c) 2022 Tjaijar et al. This is an open access article licensed under the Creative Commons Attribution-NonCommercial 4.o International License (https://creativecommons.org/licenses/by-nc/4.o/)

\title{
Development Strategy of Palu Bay Marine of Sustainable Tourism with the A'WOT Hybrid Method
}

\author{
Abunawas Tjaija $\mathbf{1}^{*}$ \\ Muhammad Nur Ali ${ }^{1}$ \\ Fadhliah $^{1}$ \\ Effendy $y^{2}$ \\ ${ }^{1}$ Faculty of Social and Political Science, Tadulako University, \\ Jl. Soekarno Hatta No.KM. 9, Tondo, Mantikulore, Kota Palu, \\ Sulawesi Tengah 94148, Indonesia \\ ${ }^{2}$ Department of Agricultural Socio-Economics, Tadulako University, \\ Jl. Soekarno Hatta No.KM. 9, Tondo, Mantikulore, Kota Palu, \\ Sulawesi Tengah 94148, Indonesia \\ ${ }^{*}$ Corresponding Author
}

DOI: https://doi.org/10.36941/ajis-2022-0024

\begin{abstract}
Sustainable development has become one of the strategic issues in the tourism industry. Sustainability is an action that combines environmental, sociocultural, and economic concepts. The tourism industry has had good benefits on economic and social growth. Still, if it is not adequately planned and managed, it can have harmful consequences on the environment. This research aims to present a sustainable development strategy for Palu Bay Marine Tourism following a natural disaster. The A'WOT hybrid method (AHP-SWOT) was used to achieve the research objectives. The A'WOT method is a combination of a SWOT analysis and the AHP method. This research was done on Palu Bay tourism, Central Sulawesi Province, Indonesia. This research resulted in a sustainable development strategy for Palu Bay tourism related to the diversity of products and improvement of event management, an improved image of Palu Bay tourism, improvement in the visitor management system to minimize environmental impacts, and efficient and effective promotion and branding.
\end{abstract}

Keywords: Development, External environment, Internal environment, SWOT, AHP

\section{Introduction}

Sustainable development is an action that combines environmental, sociocultural, and economic concepts (Font and McCabe, 2017). Sustainability has become one of the strategic issues in the tourism industry (Fiskel, 2006). The tourism industry has seen fast worldwide growth and has moved toward sustainable practices (Font et al., 2006). It has had a positive effect on economic, social, and environmental development if properly planned and managed (Fossati \& Panella, 2000). 
In order to achieve a sustainable tourism industry, it is necessary to take into account all sectors and resources that contribute to tourism development (Dodds, 2007). According to Niedziolka (2012), sustainable tourism is tourism development that preserves the environment, sociocultural aspects, and the economy. This emphasizes that all stakeholders are responsible for preserving the environmental, sociocultural, and economic balance (Muhanna, 2006; Richin, 2009).

Because of a fundamental shift in stakeholders' perceptions of tourism as a local political issue, sustainable tourism management has become a challenge for all stakeholders (Goodwin, 2017). For example, over-tourism has emerged, which is an impact of tourism that excessively affects residents' quality of life and negatively affects stakeholders (UNWTO, 2018). If the tourism industry is not managed sustainably, it could have a negative impact on both local residents and stakeholders. Thus, tourism will only be sustainable if it is created and managed with local communities and stakeholders in mind.

Palu Bay Marine Tourism is a clear case of how and why tourist destinations could lose competitiveness in the aftermath of the natural disaster that rocked Palu City on September 28, 2018 (earthquake, liquefaction, and tsunami). There was a need to revisit the Palu Bay Marine Tourism strategy which had formalized its vision and pointed out key factors that could also be used to regain ground. This research highlights the Palu Bay Marine Tourism planning strategy and explains how a new approach for competing in the tourism market was created using the A'WOT hybrid method (AHP-SWOT). The purpose of this research is to present a development strategy for sustainable Palu Bay Marine Tourism in the aftermath of a natural disaster. Findings could also be used as a reference to sustainably manage other tourism.

\section{Literature Review}

Tourism policy is a regulation, objective, and strategy for direct tourism development and daily activities at a destination (Goeldner et al., 200o). Tourism policy provides a basic philosophy for development and determines the future direction of tourism development at the destination. It also provides a quality visitor experience and gives benefits to destination stakeholders while ensuring that the destination has not compromised on its environmental, social, and cultural integrity.

A destination could be said to be carrying out tourism development if there has previously been tourism activities. In the implementation of development, planning is a factor that needs to be considered and completed. There are several approaches that have been considered in planning tourism (Inskeep, 1991), including: 1) a continuous incremental and flexible approach, 2) a system approach, 3) a comprehensive approach, 4) an integrated approach, 5) an environmental and sustainable development approach, 6) a community approach, 7) an implementable approach, and 8) the application of a systematic planning approach. These approaches emphasize the importance of maximizing the involvement of local communities in tourism planning and decision-making processes; community participation needs to be maximized in tourism development and management and with regard to its socioeconomic benefits.

At different stages of tourism development, tourism planning has had different stages, and it still has a traditional meaning ( $\mathrm{Lu} \& \mathrm{Liu}, 2016$ ), but several studies have addressed sustainable tourism as a topic (Bramwell et al., 2017; Grytsiuk et al., 2017; Zolfani, 2015). Tsaur and Wang (2007) used AHP and Fuzzy Set to assess sustainable tourist development, while Mondal (2017) and Sulistyadi et al. (2017) employed SWOT analysis and the TOWS matrix. This research used the AHP and SWOT approaches for the development of sustainable Palu Bay marine tourism.

\section{Materials and Methods}

\subsection{Research Area}

Palu Bay Marine Tourism is located in Palu City, Sulawesi, Indonesia. Palu City is located on the plains of the Palu valley and Palu Bay, with an average height of o-70o meters above sea level, at a 
position of $0^{\circ} .36^{\prime \prime}$ - $0^{\circ} .56^{\prime \prime}$ south latitude and $119^{\circ} .45^{\prime \prime}$ - 121 $1^{\circ} .1$ east longitude. The area of Palu City is $395.06 \mathrm{~km}^{2}$. (BPS, 2020). In 2019 (BPS, 2020), the administrative area of Palu City consisted of eight subdistricts and 46 urban villages, namely: West Palu $\left(8.28 \mathrm{~km}^{2}\right)$, Tatanga $\left(14.95 \mathrm{~km}^{2}\right)$, Ulujadi (40.25 $\left.\mathrm{km}^{2}\right)$, South Palu $\left(27.38 \mathrm{~km}^{2}\right)$, East Palu $\left(7.71 \mathrm{~km}^{2}\right)$, Mantikulore $\left(206.80 \mathrm{~km}^{2}\right)$, North Palu $\left(29.94 \mathrm{~km}^{2}\right)$, and Tawaeli $\left(59.75 \mathrm{~km}^{2}\right)$.

The beautiful scenery of Palu City can be traced, in part, to Talise Beach, and more precisely to bridge IV which collapsed due to the earthquake on September 28, 2018. In addition, there are still tourist attractions that are no less beautiful than Talise Beach. The people of Palu City call it the Kampung Nelayan Beach which is still in the same row as Talise Beach. The area along the coast is inhabited by people who mostly work as fishermen.

Talise Beach and the Kampung Nelayan Beach area are located in Talise Urban Village, Mantikulore Sub-District, Palu City. This location has a distance of 6 to $9 \mathrm{~km}$ from Mutiara SIS-Al Jufri Airport Palu; this means it takes about 20 minutes to reach the airport. Meanwhile, Kampung Nelayan Beach is about $3 \mathrm{~km}$ from the center of Palu City with a travel time of 10 to 15 minutes.

\subsection{Method}

The A'WOT method and the TOWS matrix were used to achieve the research objective, which was to suggest a planning strategy for sustainable Palu Bay marine tourism.

\subsubsection{A'WOT method}

The A'WOT method is a combination of AHP (Analytical Hierarchy Process) and SWOT (Strengths, Weaknesses, Opportunities, and Threats) analyses (Kangas et al., 2001; Yavuz \& Baycan, 2013). This research used the A'WOT method with the following steps (Kurttila et al., 200o; Kisi, 2019):

1. Perform SWOT analysis;

2. Using AHP, make pairwise comparisons between SWOT components in each SWOT group;

3. Using AHP, make pairwise comparisons between the four SWOT groups; and

4. Apply the findings to the strategy design and evaluation process.

SWOT analysis was the initial stage of the strategic planning process in this research. SWOT analysis was used to identify internal and external factors that affect tourism development. SWOT analysis was also used in resource allocation, situation analysis, and the gathering of important strategic information about decision making from various sources (Lozano \& Valles, 2007). However, SWOT analysis provided only a basic framework for analyzing decision making (Shrestha et al., 2004; Shinno et al., 2006).

To overcome this problem, the AHP approach, the most prevalent tool for quantitative assessment of SWOT aspects in decision making for planning (Oreski, 2012). AHP could assist in conducting a more analytical SWOT analysis by converting non-numeric values into numeric values (Leskinen et al., 2004; Yuen, 2009). To identify the importance of the components in the SWOT analysis, AHP used a paired assessment based on a nine-point scale (Table 1). (Saaty, 1990).

Table 1: Comparison scale in pairs

\begin{tabular}{|c|l|}
\hline Intensity of Interest & \multicolumn{1}{c|}{ Definition } \\
\hline 1 & Both elements are equally important \\
\hline 3 & One element is slightly more important than the other \\
\hline 5 & One element is very important than the other elements \\
\hline 7 & One element is definitely more important than the other \\
\hline 9 & One element is absolutely more important than another \\
\hline $2,4,6,8$ & Values between two adjacent considerations \\
\hline
\end{tabular}

Source: Saaty, 1990 
A questionnaire consisting of paired assessments was used to collect the research data. A list of questions related to the research was given to selected respondents and was related to research problems. In selecting respondents, it was not the sample size that mattered but their knowledge and experience in tourism (Morgan et al., 2014; Saaty \& Özdemir, 2015). Respondents were selected based on their knowledge and experience from various fields. The expert group consisted of local tourism managers, hotel managers, tourism organization managers, sociocultural managers, travel agency owners, and academics. The completed questionnaire was then processed using Expert Choice 11 software. After all of the pairwise comparisons were processed, consideration needed to be given to the Consistency Ratio (CR). If $C R<=0.10, C R$ is acceptable; if $C R>0.1$, the decision maker must revise the pairwise comparison (Ho, 2008; Sharma, 2013). These results were used in strategy formulation.

\subsubsection{TOWS Matrix}

SWOT analysis produced internal and external tourism factors, which were then weighted with AHP for each factor contained in the strengths, weaknesses, opportunities, and threats areas. Applying the AHP technique in SWOT analysis was aimed to evaluate and make SWOT factors commensurate (Wang et al., 2014). The advantage of this method is that it makes the identification of SWOT factors more quantitative and includes the involvement of decision makers in strategy formulation. The integration of the SWOT-AHP method was used to determine the factors of threats, opportunities, weaknesses, and strengths, and the results obtained from this method were the SWOT factors with the largest weight priority used to determine alternative strategies at the strategy development stage. The matrix TOWS was used to assist information analysis in the strategic choice process (Pesic, 2015). This research used the TOWS matrix suggested by Weihrich (1982).

Table 2: TOWS Matrix

\begin{tabular}{|l|l|l|}
\hline & \multicolumn{1}{|c|}{ Internal Strengths (S) } & \multicolumn{1}{c|}{ Internal Weaknesses (W) } \\
\hline $\begin{array}{l}\text { External } \\
\text { Opportunities }(\mathrm{O})\end{array}$ & $\begin{array}{l}\text { SO: Maxi-Maxi: use strengths to } \\
\text { maximize opportunities }\end{array}$ & $\begin{array}{l}\text { WO: Mini-Maxi: minimize weaknesses by } \\
\text { taking advantage of opportunities }\end{array}$ \\
\hline External Threats (T) & $\begin{array}{l}\text { ST: Maxi-Mini: use strengths to } \\
\text { minimize threats }\end{array}$ & $\begin{array}{l}\text { WT: Mini-Mini: minimize weaknesses and } \\
\text { avoid threats }\end{array}$ \\
\hline
\end{tabular}

According to Weihrich (1982), the SO (strength-opportunity) strategy is aimed to maximize the strengths and opportunities, and the ST (strength-threats) strategy was based on the strengths that could deal with threats in the environment. The WT (weaknesses-threats) strategy minimized weaknesses and threats, while the WO (weaknesses-opportunities) strategy minimized weaknesses and maximized opportunities.

\section{Results}

\subsection{SWOT Analysis}

SWOT analysis was processed through external and internal factors. Evaluation of external factors was done through literacy studies by looking for the latest issues in the tourism industry in Indonesia and conducting interviews with hotel managers, sociocultural managers, travel agency owners, and academics. According to David (2005), there are several factors that have to be considered in analyzing the external environment, namely economic factors, demographic factors, political and government factors, technological factors, and industrial competitor factors. Several issues were derived from these factors, which were then validated with company management to determine issues that affect the tourism industry.

Evaluation of internal factors, namely conducting interviews with local tourism managers and 
tourism organization managers, was also undertaken. According to David (2005), there are several factors that have to be considered in analyzing the internal environment, namely production factors, financial factors, management factors and human resource factors, marketing factors, and information technology factors. Several questions arose from these factors, which were then validated with company management to determine questions that were appropriate for the tourism industry.

The results of the analysis of the relevant factors from the internal environment (strengths and weaknesses) and external environment (opportunities and threats) as determined by the selected respondents who worked in the tourism industry are listed in Table 3.

Table 3: SWOT matrix for Palu Bay marine tourism

\begin{tabular}{|c|c|c|c|}
\hline \multicolumn{4}{|c|}{ External environment: } \\
\hline \multicolumn{2}{|l|}{ Threats } & \multicolumn{2}{|l|}{ Opportunities } \\
\hline Deteriorating global economy & $\mathrm{T} 1$ & Employment support & O1 \\
\hline Natural disaster threat & T2 & $\begin{array}{l}\text { A place for introduction and marketing of } \\
\text { regional products }\end{array}$ & $\mathrm{O}_{2}$ \\
\hline Environmental pollution & $\mathrm{T}_{3}$ & Number of tourists visiting Central Sulawesi & $\mathrm{O}_{3}$ \\
\hline Increasing number of competitors & $\mathrm{T}_{4}$ & A stopover place for people who have traveled & $\mathrm{O}_{4}$ \\
\hline $\begin{array}{l}\text { The emergence of various alternative tourist } \\
\text { objects in the vicinity. }\end{array}$ & $\mathrm{T}_{5}$ & Mutiara SIS Al-Jufri airport service & $\mathrm{O}_{5}$ \\
\hline \multicolumn{4}{|c|}{ Internal environment: } \\
\hline \multicolumn{2}{|l|}{ Weaknesses } & \multicolumn{2}{|l|}{ Strength } \\
\hline $\begin{array}{l}\text { There was still a lack of tourist attraction facilities } \\
\text { and infrastructure }\end{array}$ & W1 & $\begin{array}{l}\text { Had a panoramic view of the beach and } \\
\text { adequate seawater quality }\end{array}$ & S1 \\
\hline $\begin{array}{l}\text { Lack of promotional activities on cultural and } \\
\text { natural wealth }\end{array}$ & $\left|\mathrm{W}_{2}\right|$ & $\begin{array}{l}\text { Located on the road network transition path / } \\
\text { easy to access. }\end{array}$ & S2 \\
\hline $\begin{array}{l}\text { The location was close to the protocol road so it } \\
\text { threatened the safety of visitors }\end{array}$ & $\left|\mathrm{W}_{3}\right|$ & Some natural beaches & $\mathrm{S}_{3}$ \\
\hline Lack of coordination between institutions & $\mathrm{W}_{4}$ & Sailboat event (community boats) & $\mathrm{S}_{4}$ \\
\hline Lack of awareness about tourism potential & $\mathrm{W}_{5}$ & $\begin{array}{l}\text { The existence of culinary tourism (local } \\
\text { products) was a complement to beach tourism }\end{array}$ & $\mathrm{S}_{5}$ \\
\hline $\begin{array}{l}\text { There was no management from the local } \\
\text { government (still managed by each community) }\end{array}$ & W6 & $\begin{array}{l}\text { Based on the position, it was safe from the } \\
\text { water's current }\end{array}$ & S6 \\
\hline Incomplete services & $\mathrm{W}_{7}$ & $\begin{array}{l}\text { Availability of marine tourism equipment } \\
\text { (community boats) }\end{array}$ & $\mathrm{S}_{7}$ \\
\hline
\end{tabular}

\subsection{Hierarchical Modeling}

In formulating a strategy using the A'WOT method, the first thing to be done was to create a hierarchical structure of the A'WOT model. The structure used in this research had the main objective of achieving the vision of Palu Bay Marine Tourism (Figure 1).

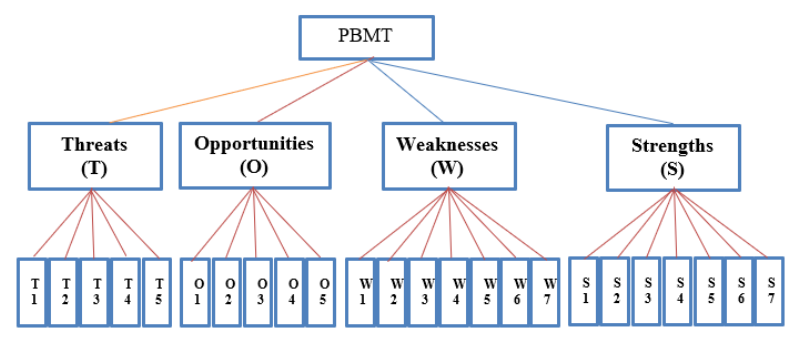

Figure 1: Hierarchical model of sustainable tourism development of Palu Bay Marine Tourism 


\subsection{Priority of External and Internal Environmental Factors}

After making the hierarchical process with pairwise comparisons, the results obtained were processed using Expert Choice software version 200o. The consistency ratio (CR) value for each comparison matrix was less than o.10. Table 4 shows the results of processing pairwise comparison data using Expert Choice.

Table 4: Priority of groups and priority of SWOT factors based on AHP

\begin{tabular}{|c|c|c|c|c|c|c|c|}
\hline Criteria & Priority of group & Sub-criteria & Priority Factor & Criteria & Priority of group & Sub-criteria & Priority Factor \\
\hline $\mathrm{S}$ & 0.26 & $\mathrm{~S}_{1}$ & 0.3252 & $\mathrm{~W}$ & $\mathrm{0.24}$ & $\mathrm{W}_{1}$ & 0.2163 \\
\hline & & $\mathrm{S}_{2}$ & 0.0803 & & & $\mathrm{~W}_{2}$ & 0.2959 \\
\hline & & $\mathrm{S}_{3}$ & 0.1705 & & & $\mathrm{~W}_{3}$ & 0.0917 \\
\hline & & $\mathrm{S}_{4}$ & 0.1022 & & & $\mathrm{~W}_{4}$ & 0.1624 \\
\hline & & $\mathrm{S}_{5}$ & 0.0983 & & & $\mathrm{~W}_{5}$ & 0.0587 \\
\hline & & $\mathrm{S} 6$ & 0.0934 & & & $\mathrm{~W}_{6}$ & 0.0885 \\
\hline & & $\mathrm{S}_{7}$ & 0.1302 & & & $\mathrm{~W}_{7}$ & 0.0866 \\
\hline $\mathrm{O}$ & 0.25 & $\mathrm{O}_{1}$ & 0.3210 & $\mathrm{~T}$ & 0.25 & $\mathrm{~T}_{1}$ & 0.1338 \\
\hline & & $\mathrm{O}_{2}$ & 0.0911 & & & $\mathrm{~T}_{2}$ & 0.2296 \\
\hline & & $\mathrm{O}_{3}$ & 0.0901 & & & $\mathrm{~T}_{3}$ & 0.3314 \\
\hline & & $\mathrm{O}_{4}$ & 0.0900 & & & $\mathrm{~T}_{4}$ & 0.1554 \\
\hline
\end{tabular}

Table 4 shows that the greatest strengths in terms of Palu Bay marine tourism are adequate beach panorama, seawater quality (0.3252), and many natural beaches (0.1705), along with the availability of marine tourism equipment, such as community boats (0.1302). The most important opportunities offered by external environmental factors that should be exploited were Mutiara SIS Al-Jufri Airport (o.4101) and employment support (0.3210). The most important weaknesses of Palu Bay marine tourism were the lack of cultural promotional activities and natural wealth (0.2959) and the lack of tourist attraction facilities and infrastructure (0.2163). The main external environmental threats affecting Palu Bay marine tourism were environmental pollution (0.3314) and the threat of natural disasters (0.2296).

\subsection{Development Strategy}

The development strategy of sustainable Palu Bay marine tourism is presented in accordance with the region's vision statement and the primary objectives of sustainable tourism. The vision statement of Palu City was to build a Palu City that was independent, safe, and comfortable; resilient; and professional in the context of sustainable development based on local wisdom and religion. The sustainable marine tourism strategy in Palu City was identified as the development of a sustainable tourism industry by distributing tourism activities in Central Sulawesi based on the Indonesian Tourism Strategy (Asvaliantina, 2019) and the definition of sustainable tourism (Dodds, 2007; UNWTO, 2018). Therefore, a development strategy for Palu bay marine tourism was determined as follows (Font et al., 2017; Asvaliantina, 2019):

Strategy $1(\mathrm{STR} 1)=$ Providing high experience satisfaction to visitors;

Strategy $2(\mathrm{STR} 2)=$ Providing economic benefits and increasing the welfare of local communities as well as providing an expansion of employment opportunities; and

Strategy $3\left(\mathrm{STR}_{3}\right)=$ Minimizing environmental impact and preserving the authenticity of Palu City.

Based on the internal and external factors in Table 3 and the priorities that were obtained from the results of the A'WOT analysis, several alternative strategies were developed. These alternative 
strategies were then matched with several strategic theories taken from the literature to look for some tourism that has done the same thing. Several strategies were then formulated as shown in Table 5 .

Table 5: Strategy formulation using TOWS matrix

\begin{tabular}{|c|c|c|c|c|}
\hline & \begin{tabular}{|c|}
$\begin{array}{c}\text { Strategy } \\
\text { (STR) }\end{array}$ \\
\end{tabular} & $\begin{array}{l}\text { Strengths } \\
(\mathrm{S})\end{array}$ & \begin{tabular}{|c|}
$\begin{array}{c}\text { Strategy } \\
\text { (STR) }\end{array}$ \\
\end{tabular} & $\begin{array}{c}\text { Weaknesses } \\
(\mathrm{W})\end{array}$ \\
\hline $\begin{array}{l}\text { Opportunities } \\
\text { (O) }\end{array}$ & $\begin{array}{l}\text { STR1- } \\
\text { STR2 }\end{array}$ & $\begin{array}{l}\text { SO Strategy: Product } \\
\text { diversification and } \\
\text { improving event } \\
\text { management }\left(\mathrm{S}_{1}, \mathrm{~S}_{2}, \mathrm{~S}_{3},\right. \\
\mathrm{S}_{4}, \mathrm{~S}_{5}, \mathrm{~S}_{6}, \mathrm{~S}_{7}, \mathrm{O}_{1}, \mathrm{O}_{2}, \\
\left.\mathrm{O}_{3}, \mathrm{O}_{4}, \mathrm{O}_{5}\right) \\
\text { - Forming an } \\
\text { organization that organizes } \\
\text { tourism events globally } \\
\text { - Promote local products. } \\
\end{array}$ & $\begin{array}{l}\text { STR1- } \\
\text { STR3 }\end{array}$ & $\begin{array}{l}\text { WO Strategy Increasing the image of } \\
\text { Palu Bay tourism }\left(\mathrm{W}_{1}, \mathrm{~W}_{2}, \mathrm{~W}_{5}, \mathrm{~W} 6, \mathrm{O}_{1} \text {, }\right. \\
\left.\mathrm{O}_{2}, \mathrm{O}_{3}, \mathrm{O}_{4}, \mathrm{O}_{5}\right) \\
\text { - Determine efficient and effective travel } \\
\text { routes } \\
\text { - Development of tourism management } \\
\text { organizations to organize events globally } \\
\text { - Preserve tourism infrastructure } \\
\text { - Promote the development and } \\
\text { protection of local products. }\end{array}$ \\
\hline Threats (T) & $\begin{array}{l}\mathrm{STR}_{1-} \\
\mathrm{STR}_{3}\end{array}$ & $\begin{array}{l}\text { ST Strategy Improve visitor } \\
\text { management } \\
\text { system to minimize } \\
\text { environmental impact } \\
\left(\mathrm{S}_{1}, \mathrm{~S}_{2}, \mathrm{~S}_{3}, \mathrm{~S}_{4}, \mathrm{~S}_{5}, \mathrm{~S} 6,\right. \\
\left.\mathrm{S}_{7}, \mathrm{~T}_{3}, \mathrm{~T}_{4}, \mathrm{~T}_{5}\right) \\
\text { - Provide tourist guides } \\
\text { - Provide guidance on } \\
\text { community tourism } \\
\text { entrepreneurship in optimal } \\
\text { utilization of tourism resources } \\
\text { - Training for stakeholders } \\
\text { to reduce and recycle waste. }\end{array}$ & $\begin{array}{l}\text { STR1- } \\
\text { STR2- } \\
\text { STR3 }\end{array}$ & $\begin{array}{l}\text { WT Strategy } \\
\text { Carry out efficient and effective } \\
\text { promotion and branding ( } \mathrm{W}_{1}, \mathrm{~W}_{2}, \mathrm{~W}_{4} \text {, } \\
\left.\mathrm{T}_{1}, \mathrm{~T} 2\right) \\
\text { - Palu bay tourism advertisement } \\
\text { globally } \\
\text { - Establish partnerships and cooperation } \\
\text { - Strengthening relations between } \\
\text { tourism and other industrial sectors } \\
\text { - Empowering stakeholders in the } \\
\text { application of sustainable principles. }\end{array}$ \\
\hline
\end{tabular}

\section{Discussion}

\subsection{Priority External and Internal Environmental Factors}

The formulation of the Palu Bay marine tourism development strategy was accomplished through the A'WOT hybrid approach. The results of the analysis show that the greatest strengths in terms of sustainable Palu Bay marine tourism are having beach panoramas and adequate seawater quality, the number of natural beaches, and the availability of marine tourism equipment (community boats). Palu City is known as one of the areas in Indonesia that has a bay called Palu Bay. This region has a rough topography and is rich in flora and fauna. The beauty of Palu Bay could be observed from Talise Beach. In addition, there is still a tourist attraction that is no less beautiful than Talise Beach, namely Kampung Nelayan Beach which is in the same row as Talise Beach. The area along the coast is inhabited by people who mostly work as fishermen. From the Kampung Nelayan Beach, you can see the Gawalise mountain range which is neatly lined up as if it fences off Palu Bay. The panorama of natural beauty is more complete with a clean beach environment. Along the coastline of Talise Beach, we can find Talise trees (ketapang) which are the forerunner of the name Talise Urband Village. The atmosphere of the Kampung Nelayan beach is more beautiful in the morning. We could see the sun rising over the mountains. This sunrise phenomenon was more beautiful with the reflection of sunlight on the surface of the seawater that looked luminous. Managing natural heritage values is important in sustainable tourism planning (Kisi, 2019). In this case, beach tourism. Coastal tourism could increase the welfare of local communities (Okonkwo et 
al., 2017; Manurung et al., 2019). Marine tourism creates a synergy between tourism and sport as a sustainable tourism offering (Milojica et al., 2014). These strengths would be one of the assets in the development of sustainable Palu Bay marine tourism.

The most important opportunities offered by external environmental factors that need to be exploited are Mutiara SIS Al-Jufri Airport and employment support. Mutiara SIS Al-Jufri Airport which provides air transportation could increase the quality perceived by tourist visitors (MartinCejas, 2006). Mutiara SIS Al-Jufri Airport would play an important role in the development of Palu Bay marine tourism. The number of tourist visits supported employment. Therefore, this opportunity has to be optimally utilized in the development of sustainable Palu Bay marine tourism. In addition to the strengths and opportunities, there were also weaknesses and threats to Palu Bay marine tourism. The most important weaknesses of Palu Bay marine tourism are the lack of cultural promotional activities and natural wealth as well as the lack of tourist attraction facilities and infrastructure. The lack of promotional activities related to the cultural and natural wealth of Palu Bay marine tourism would have a major impact on the global tourism market, thereby reducing competitiveness. Promotion is an effective tool to maintain the target for tourist visits (Mulec, 2009). Tourist attraction facilities and infrastructure were an integral part of the Palu Bay marine tourism package. Facilities and infrastructure for tourist attractions are needed to meet the needs of tourists (Seetanah et al., 2011). The quality of infrastructure is an important indicator of the competitiveness and level of development of a region in the tourism sector. The main external environmental threats that affected Palu Bay marine tourism were environmental pollution and the threat of natural disasters. To minimize environmental pollution and the threat of natural disasters, the authorities have to carry out tourism management in the context of environmental sustainability (Kisi, 2019) and control the threat of natural disasters, such as early warning of a natural disaster.

\subsection{Development Strategy}

The development strategy of sustainable Palu Bay marine tourism in Palu City was stated as providing high experience satisfaction to visitors, providing economic benefits, and increasing the welfare of local communities as well as providing an expansion of employment opportunities, minimizing environmental impacts, and preserving the authenticity of Palu City. To be able to achieve the objective of sustainable Palu Bay marine tourism, it is necessary to diversify products and wisely improve event management (Weidenfeld, 2018; Kisi, 2019), for example, it is necessary to continuously hold community boat events to attract tourists (Higgins-Desbiolles, 2018). These things are organized to provide high experience satisfaction for visitors (STR1). The results of this study are supported by research by Klimek (2013) and Sulistyadi et al. (2017) which stated that events in tourism could affect sustainable tourism. In a sustainable context, all owned resources have to be protected and efficiently and effectively used. In the context of sustainable tourism development, tourism competitiveness rests on the owned resources; in particular, the coastal panorama and seawater quality, which were the strongest assets, have to be protected and efficiently and effectively used. Likewise, other resources such as natural beaches, road networks, natural beaches, community boat events, local products, a position safe from currents, and marine tourism equipment (community boats) need to be evaluated for event management. Sustainable Palu Bay marine tourism could also provide benefits to local communities. The development of Palu Bay marine tourism could benefit the economy of the local community (Tsaur \& Wang, 2007). To provide economic benefits and increase the welfare of local communities (STR2), an incentive-based entrepreneurial approach should be developed. For example, coastal tourism, community boat tourism, and culinary tourism (local products) could be appreciated because they could encourage a more balanced economic growth in accordance with local environmental and sociocultural issues (Zargham, 2007). The increasing demand for local products would increase the local community economy.

Another topic for a sustainable Palu Bay marine tourism development strategy in Palu City was related to increasing the image of Palu Bay tourism to achieve effective marketing (Liu, 2017). 
Increasing the tourism image of Palu Bay would increase the number of tourist visitors. The program to preserve tourism infrastructure, development, and protection of local products was a program to help increase the image of Palu Bay tourism. This was to provide a high experience satisfaction for visitors (STR1). Palu Bay marine tourism activities have to be done with environmental management that minimizes environmental impacts and preserves the authenticity of Palu City (STR3). Mondal (2017) stated that the development of sustainable tourism infrastructures requires more regulation. The development of infrastructure (facilities and infrastructure for tourist attraction) of Palu Bay marine tourism plays an important role because it could affect the competitiveness and level of visitor satisfaction. In addition, effective promotions need to be done to increase global competitiveness (Golja \& Nizic, 2010). Promotional strategies could bring a competitive advantage to a tourist destination (Kisi, 2019). The lack of promotional activities on cultural and natural wealth was one of the weaknesses in the development of Palu Bay marine tourism. Cortez (2010) and Grytsiuk et al. (2017) suggested promotional strategies to increase tourist visitors and benefit visitors and local communities.

Improving the visitor management system to minimize environmental impact was one way to provide a high satisfaction experience to visitors ( $\mathrm{STR}_{1}$ ), namely, by providing tourist visitor guides, tourism entrepreneurship guidelines, and training for stakeholders to preserve the environment. According to Tsaur and Wang (2007), tourism development could be harmful to the environment. The most important threats to Palu bay tourism were environmental pollution and natural disasters. To minimize environmental impact and preserve the authenticity of Palu City ( $\mathrm{STR}_{3}$ ), tourism managers have to act in the context of sustainability and promote the identity and culture of Palu city. This could be done through training on sustainable tourism (waste reduction and recycling) and advertisements on the sociocultural aspects of Palu City.

When implemented, this efficient and effective promotion and branding complements other sustainable Palu Bay marine tourism development strategies. The program could be carried out by globally using Palu Bay tourism advertisements, establishing partnerships and collaborations, strengthening relations between tourism and other industrial sectors, and empowering stakeholders in the application of sustainable principles. These activities have been effective to support tourism development (Graci, 2013; Nowacki et al., 2018; Paunovic \& Jovanovic, 2017). The implementation of this strategy would provide a high experience satisfaction to visitors (STR1), provide economic benefits, and increase the welfare of local communities, as well as provide an expansion of job opportunities (STR2).

\section{Conclusion}

Sustainable tourism development has become an important issue because the worldwide growth of the tourism industry has had a negative impact on sociocultural structure and natural resources. This research used the A'WOT method to strengthen the quantitative side in the development of the tourism industry. The results of the analysis show that there were many weaknesses and environmental threats, but that Palu bay has a lot of tourism potential that needs to be managed sustainably. The development of Palu Bay marine tourism has to consider product diversification strategies, improve event management, increase the image of Palu Bay tourism, improve visitor management systems to minimize environmental impacts, and carry out efficient and effective promotion and branding.

\section{References}

Asvaliantina, V. (2019). Strategi Pengembangan Pariwisata Bahari Berstandar Internasional. Kepala Bidang Infrastruktur Pariwisata Bahari Asisten Deputi Infrastruktur Pelayaran, Perikanan, dan Pariwisata Kementerian Koordinator Bidang Kemaritiman dan Investasi.

BPS. (2020). Kota Palu dalam angka. Badan Pusat Statistik (BPS) Kota Palu. 
Bramwell, B., Higham, J., Lane, B. \& Miller, G. (2017). Twenty Five Years of Sustainable Tourism and the Journal of Sustainable Tourism: Looking Back and Moving Forward. J. Sustain. Tour., 25, 1-9.

Cortez, S.L. (2010). Strategies for the Development of Sustainable Tourism in the Amazon Rainforest of Bolivia. Worldw. Hosp. Tour. Themes, 2, 136-143.

David, F. R. (2005). Strategic Management concept and cases, South Carolina: Pearson Education International.

Dodds, R. (2007). Sustainable Tourism and Policy Implementation: Lessons from the Case of Calvia, Spain. Curr. Issues Tour., 10, 296-322.

Fiskel, J. (2006). Sustainability and Resilience: Towards a System Approach. Sustain. Sci. Pract. Policy, 2, 1-8.

Font, X. \& Mccabe, S. (2017). Sustainability and Marketing in Tourism: Its Contexts, Paradoxes, Approaches, Challenges and Potential. J. Sustain. Tour, 25, 869-883.

Font, X. \& Tapper, R. \& Cochrane, J. (2006). Competitive Strategy in a Global Industry: Tourism. Handb. Bus. Strategy, 7, 51-55.

Fossati, A. \& Panella, G. (200o). Tourism and Sustainable Economic Development; Kluwer Academic Publishers: New York, NY, USA, ISBN 978-1-4613-6940-o.

Goeldner, R., Ritchie, B.R.J. \& McIntosh, W.R. (200o). Tourism: Principles, Practices, Philosophies. Jon Willey \& Sons, Canada.

Golja, T. \& Nizic, M.K. (2010). Corporate Social Responsibility in Tourism-The Most Popular Tourism Destinations in Croatia: Comparative Analysis. Management, 15, 107-121.

Goodwin, H. (2017). The Challenge of Overtourism. Responsible Tourism Partnership Working Paper 4.1-19, October 2017.Available online: http://haroldgoodwin.info/pubs/RTP \T1 \textquoteleftWP4 Overtourismo1 \T1 \textquoteright2017.pdf

Graci, S. (2013). Collaboration and Partnership Development for Sustainable Tourism. Tour. Geogr, 15, $25-42$.

Grytsiuk, M., Grytsiuk, P. \& Gryciuk, Y. (2017). Building a Sustainable Tourism Development Strategy in the Carpathian Region of Ukraine. Sci. Pap. Sil. Univ. Technol. Organ. Manag. Ser., 35-50.

Grytsiuk, M., Grytsiuk, P. \& Gryciuk, Y. (2017). Building a Sustainable Tourism Development Strategy in the Carpathian Region of Ukraine. Sci. Pap. Sil. Univ. Technol. Organ. Manag. Ser., 35-50.

Higgins-Desbiolles, F. (2018). Event Tourism and Event Imposition: A Critical Case Study from Kangaroo Island, South Australia. Tour. Manag., 64, 73-86.

Ho, W. (2008). Integrated Analytic Hierarchy Process and Its Applications-A Literature Review. Eur. J. Oper. Res., $186,211-228$.

Inskeep, E. (1998). Guide for local Authorities on Developing Sustainable Tourism. World Tourism Organization, New York.

Kangas, J., Pesonen, M., Kurttila, M. \& Kajanus, M. (2001). A'WOT: Integrating the AHP with SWOT Analysis. In Proceedings of the 6th ISAHP, Berne, Switzerland, 2-4 August 2001.

Kisi, N. (2019). A Strategic Approach to Sustainable Tourism Development Using the A'WOT Hybrid Method: A Case Study of Zonguldak, Turkey. Sustainability, 11, 964, doi:10.3390/su11040964

Klimek, K. (2013). Destination Management Organisations and their Shift to Sustainable Tourism Development. Eur. J. Tour. Hosp. Recreat., 4, 27-47.

Kurttila, M. Pesonen, M., Kangas, J. \& Kajanus, M. (200o). Utilizing the Analytical Hierarchy Process (AHP) in SWOT Analysis-A Hybrid Method and Its Application to a Forest-Certification Case. For. Policy Econ., 1, 4152.

Leskinen, L.A. Leskinen, P. Kurttila, M., Kangas, J. \& Kajanus, M. (2004). Adapting Modern Strategic Decision Support Tools in the Participatory Strategy Process-A Case Study of a Forest Research Station. For. Policy Econ., 8, 1-12.

Liu, Y.Y. (2017). Destination Images for Marketing Sustainable Tourism Destinations. Econ. Bus., 11, 520-525.

Lozano, M. \& Valles, J. (2007). An Analysis of the Implementation of an Environmental Management System in a Local Public Administration. J. Environ. Manag., 82, 495-511.

Lu, C. \& Liu, S. (2016). Cultural Tourism O2O Business Model Innovation - A Case Study of CTrip. Journal of Electronic Commerce in Organizations, 14(2), 16-31.

Manurung, K., Basir-Cyio, M., Basri, H. \& Effendy. (2019). The Development and Potential Evaluation of Indonesia Lore Lindu National Park Ecotourism in Relation to the Economic Growth of the Surrounding Community. Journal of Environmental Management and Tourism, (Volume X, Spring), 2(34): 366-373. DOI:10.14505/jemt.v10.2(34).11

Martin-Cejas, R.R. (2006). Tourism Service Quality Begins at the Airport. Tour. Manag., 27, 874-877.

Milojica, V., Drpic, D. \& Nakovski, D. (2014). Developing Hunting Tourism-A New Perspective of Achieving Competitiveness of Rural Croatia. Presented at the 3rd International Scientific Symposium Economy of Eastern Croatia-Vision and Growth, Osijek, Croatia, 22-24 May 2014. 
Mondal, M.S.H. (2017). SWOT Analysis and Strategies to Develop Sustainable Tourism in Bangladesh. UTMS J. Econ., 8, 159-167.

Morgan, R., Lesueur, M. \& Henichart, L.M. (2014). Fisheries Diversification: A Case Studyof French and English Fishers in the Channel. In Social Issues in Sustainable Fisheries Management; Urquhart, J., Acott, T.G., Symes, D., Zhao, M., Eds.; Mare Publication Series; Springer: Dordrecht, The Netherlands; Heidelberg, Germany; New York, NY, USA; London, UK, pp. 165-182. ISBN 978-94-007-7910-5.

Muhanna, E. (2006). Sustainable Tourism Development and Environmental Management for Developing Countries. Probl. Perspect. Manag., 4, 14-30.

Mulec, I. (2009). Promotion as a Tool in Sustaining the Destination Marketing Activities. Turizam, 14, 13-21.

Niedziolka, I. (2012). Sustainable Tourism Development. Reg. Form. Dev. Stud., 8, 157-166.

Nowacki, M., Kowalczyk-Aniol, J., Krolikowska, K., Pstrocka-Rak, M. \& Awedyk, M. (2018). Strategic Planning for Sustainable Tourism Development in Poland. Int. J. Sustain. Dev. World, 25, 562-567.

Okonkwo, E.E., Afoma, E. \& Martha, I. (2017). Cave Tourism and its Implications to Tourism Development in Nigeria: A Case Study of Agu-Owuru Cave in Ezeagu. Int. J. Res. Tour. Hosp., 3, 16-24.

Oreski, D. (2012). Strategy Development by Using SWOT-AHP. TEM J., 1, 283-291.

Participatory decision making tool in watershed management. Procedia Technology, 8: 134 - 143.

Paunovic, I. \& Jovanovic, V. (2017). Implementation of Sustainable Tourism in the German Alps: A Case Study. Sustainability, 9, 226.

Pesic, D., Pesic, A., Ivkovic, S. \& Apostolovic, D. (2015). Fuzzification of the 'Tows' Strategic Concept: A Case Study of the Magneti Marelli Branch in the Serbian Automotive Industry. S. Afr. J. Ind. Eng., 26, 203-217

Richins, H. (2009). Environmental, Cultural, Economic and Socio-Community Sustainability: A Framework for Sustainable Tourism in Resort Destinations. Environ. Dev. Sustain., 11, 785-8oo.

Saaty, T.L. \& Özdemir, M.S. (2015). How Many Judges Should There Be in a Group? Ann. Data Sci., 1, $359-368$.

Saaty, T.L. (1990). How to Make a Decision: The Analytic Hierarchy Process. Eur. J. Oper. Res., 48, 9-26.

Seetanah, B., Juwaheer, T.D., Lamport, M.J., Rojid, S., Sannassee, R.V. \& Subadar Agathee, U. (2011). Does Infrastructure Matter in Tourism Development? Univ. Maurit. Res. J., 17, 89-108.

Sharma, M. (2013). Multi Attribute Decision Making Techniques. Int. J. Res. Manag. Sci. Technol., 1, 49-51.

Shinno, H., Yoshioka, H., Marpaung, S. \& Hachiga, S. (2006). Quantitative SWOT Analysis on Global Competitiveness of Machine Tool Industry. J. Eng. Des., 17, 251-258.

Shrestha, R.K., Alavalapati, J.R.R. \& Kalmbacher, R.S. (2004). Exploring the Potential for Silvopasture Adoption in South-Central Florida: An Application of SWOT-AHP Method. Agric. Syst., 81, 185-199.

Sulistyadi, Y., Eddyono, F. \& Hasibuan, B. (2017). Model of Sustainable Tourism Development Strategy of the Thousand Islands Tourism Area-Jakarta. J. Econ. Manag. Trade, 19, 1-17.

Tsaur, S.H. \& Wang, C.H. (2007). The Evaluation of Sustainable Tourism Development by Analytic Hierarchy Process and Fuzzy Set Theory: An Empirical Study on the Green Island in Taiwan. Asia Pac. J. Tour. Res., 12, 127-144.

UNWTO. (2018). Overtourism? Understanding and Managing Urban Tourism Growth beyond Perceptions. Available online: https://www.e-unwto.org/doi/pdf/10.18111/9789284420070

Wang, X.P., Zhang, J. \& Yang, T. (2014). "Hybrid SWOT Approach for Strategic Planning and Formulation in China Worldwide Express Mail Service." Journal of Applied Research and Technology, 12: 230-238.

Weidenfeld, A. (2018). Tourism Diversification and Its Implications for Smart Specialisation. Sustainability, $10,319$. Weihrich, H. (1982). The TOWS Matrix-A Tool for Situational Analysis. Long Range Plan., 15, 54-66.

Yavuz, F. \& Baycan, T. (2013). Use of swot and analytic hierarchy process integration as a

Yuen, K.K.F. (2009). Analytic Hierarchy Prioritization Process in the AHP Application Development: A Prioritization Operator Selection Approach. Appl. Soft Comput., 10, 975-989.

Zargham, H. (2007). Sustainable Tourism Development and Handicrafts in the Developing World. Trans. Ecol. Environ., 102, 111-117.

Zolfani, S.H., Sedaghat, M., Maknoon, R. \& Zavadskas, E.K. (2015). Sustainable Tourism: A Comprehensive Literature Review on Frameworks and Applications. Econ. Ekon. Istraz., 28, 1-30. 